\title{
DESIGN OF MULTIFUNCTION SIMULATOR FOR ENGINE ROOM PERSONNEL TRAINING
}

\author{
Artem Ivanov $^{1}$, Igor Kolosov ${ }^{2}$, Vadim Danyk ${ }^{1}$, Sergey Voronenko ${ }^{1}$, Yurii Lebedenko ${ }^{3}$, Hanna Rudakova ${ }^{3}$ \\ ${ }^{1}$ Kherson State Maritime Academy, Department of Ship Electrical Equipment and Automatic Devices Operation, Kherson, Ukraine, ${ }^{2}$ Marlow Navigation Ukraine, Odessa, \\ Ukraine, ${ }^{3}$ Kherson National Technical University, Department of Automation, Robotics and Mechatronics, Kherson, Ukraine
}

\begin{abstract}
International requirements for improving energy efficiency and environmental protection and the necessary goals for their implementation in the marine industry are an actual problem. To integrate state-of-the-industry technologies and marine specialists education, the training complex is proposed. It is based on the platform of a hardware-software complex with the ability to integrate training equipment, simulators and software. That makes such a training complex multitask, universal, and flexible in achieving a variety of tasks and goals. The complex also implements high-quality education and training of marine specialists, conducting research after processing working out the results of engineering modelling of structural, thermal power, hydraulic, electrical, electronic, multi-physical and other solutions. The need to use the training complex allows us to form the necessary competence of the engine team personnel, develop methods and criteria for assessing competence, evaluate and demonstrate practical skills.
\end{abstract}

Keywords: power systems, standards activities, energy efficiency, training, performance evaluation

\section{PROJEKTOWANIE WIELOFUNKCYJNEGO SYMULATORA DO SZKOLENIA PERSONELU MASZYNOWNI}

Streszczenie. Międzynarodowe wymogi dotyczace poprawy efektywności energetycznej i ochrony środowiska oraz cele niezbędne do ich wdrożenia w przemyśle morskim stanowia aktualny problem. W celu zintegrowania najnowocześniejszych technologii i kształcenia specjalistów z branży morskiej proponuje się utworzenie kompleksu szkoleniowego. Jest on oparty na platformie kompleksu sprzętowo-programowego z możliwościa integracji sprzętu szkoleniowego, symulatorów i oprogramowania. To sprawia, że taki kompleks jest wielozadaniowy, uniwersalny $i$ elastyczny $w$ realizacji różnorodnych zadań i celów. Ponadto kompleks realizuje wysokiej jakości kształcenie i szkolenie specjalistów morskich, prowadzac badania po opracowaniu wyników modelowania inżynierskiego rozwiazań konstrukcyjnych, cieplnych, hydraulicznych, elektrycznych, elektronicznych, i innych. Wykorzystanie kompleksu szkoleniowego pozwala na ksztaltowanie niezbędnych kompetencji personelu zespotu inżynierskiego, opracowanie metod $i$ kryteriów oceny kompetencji, ocenę i wykazanie umiejętności praktycznych

Słowa kluczowe: systemy zasilania, działania w zakresie standaryzacji, efektywność energetyczna, szkolenia, ocena wydajności

\section{Introduction}

With the advancements in technology and the need to perform a wide range of various tasks and functions in the marine industry, a huge number of different in classes and purpose types of ships are used.

The operational profile of vessels has become more diverse and the implementation of numerous tasks leads to an increase of ship's power plants power and the difficulty in performing various marine operations. Because of this, the trade-off between efficiency and adaptability to perform various tasks has led to the appearance of various types of the ship's propulsion systems [1].

Those ship propulsion architectures contain mechanical propulsion, electrical propulsion or a hybrid combination of both; generating electricity with internal combustion engines, fuel cells, energy storage or a hybrid combination; alternating or direct currents electrical distribution systems. Most notably, such technologies require implementation in order to increase energy efficiency and environmental protection.

Taking into account all of the above-mentioned requirements and goals which are necessary for implementation into the marine industry, the actual problem is the integration of state-of-theindustry technologies and the appropriate training of marine specialists.

\section{International requirements for marine industry}

International Maritime Organization (IMO) - Marpol regulations have set targets for reducing the Energy Efficiency Design Index (EEDI) for marine vessels, which should significantly reduce fuel consumption and emissions into the environment and, therefore, IMO - Marpol increased control and enforcing these advances [7].

On January 1, 2015, Annex VI of MARPOL 73/78 entered into force on the issue of limiting emissions of combustion products into the atmosphere, which defines the limit of sulfur content in marine fuel at the level of $0.1 \%$ [6]. This annex, in particular, lists the sea basins, which are called SECA (Sox Emission Control Areas). Those are sulfur compound emission control zones, where, oxide emissions of sulfur are controlled and the restrictions on its content in marine fuel are functioned.

In addition to Marpol, as part of the IMO, one of the Marine Environment Protection Committee (MEPC) adopted the resolution "Ship energy efficiency management plan (SEEMP)" [8]. Based on SEEMP, a guide on the best practices for the fuelefficient operation of ships was developed. It includes a list of energy efficiency measures for fuel-efficient operations; power management; development software for calculating fuel consumption, controlling emissions, optimizing goal-setting operations to improve and track progress. This guide also includes renewable energy sources (wind energy, solar or photovoltaic cells), which have improved significantly in recent years and should be considered for use on ships; the possibility of obtaining fuel of improved quality to minimize the amount of fuel needed to provide a given output power and much more.

SEEMP provides a feasible approach for monitoring vessel and fleet performance. The goal of SEEMP is to create a mechanism for improving the energy efficiency of ship operations. The structure of SEEMP includes planning, implementation and monitoring:

Planning is the most important stage of SEEMP, since it primarily determines the current state of the ship's energy consumption and the expected improvement in ship's energy efficiency. It includes ship special measures (speed optimization, weather routing, and maintenance), company-specific measures (ship-repair yards, shipowners, operators, charterers, cargo owners, ports and traffic management services) and the development of human resources (raising awareness and providing the necessary personnel training both onshore and onboard).

In the Implementation process, after the vessel and the company have identified the measures that should be implemented, it is important to create a system for implementing certain measures and developing energy management procedures by defining tasks and assigning them to the qualified personnel.

Monitoring is a stage, the basis of which is continuous and consistent data collection. To ensure meaningful and consistent monitoring, a monitoring system, including procedures for collecting data and appointing responsible personnel, should be developed. 
To evaluate the effectiveness of decisions made by staff, it is necessary that the SEEMP structure has a Self-Assessment phase and improvement as the last stage of the management cycle. This phase should provide significant feedback for the upcoming first stage. The purpose of the self-assessment is to assess the effectiveness of the planned measures and their implementation in order to deeper reveal and understanding of the overall characteristics of the ship operation.

\section{Training of marine personnel}

For marine personnel to acquire the skills working with ship systems, training complexes are widely used.

Simulator training enables the use of both ready-made solutions and models of ship systems, as well as the creation of scenarios and specific training tasks, such as:

- to reproduce the operational capabilities of the appropriate ship's equipment as close as possible to the conditions of a real ship with physical reality;

- to reproduce a variety of conditions, which may include an accident, unusual or emergency situations, as well as situations that are potentially and really possible with ship's propulsion systems operation;

- to create the conditions for human behaviour with sufficient reality allowing the person to undergo training and to acquire the necessary skills;

- to monitor, observe and record the actions of people, undergoing the training, to conduct their effective debriefing and playback exercises;

- to simulate abnormal situations and equipment fault.

In Fig. 1 the structure of training of marine specialists on simulators is shown.

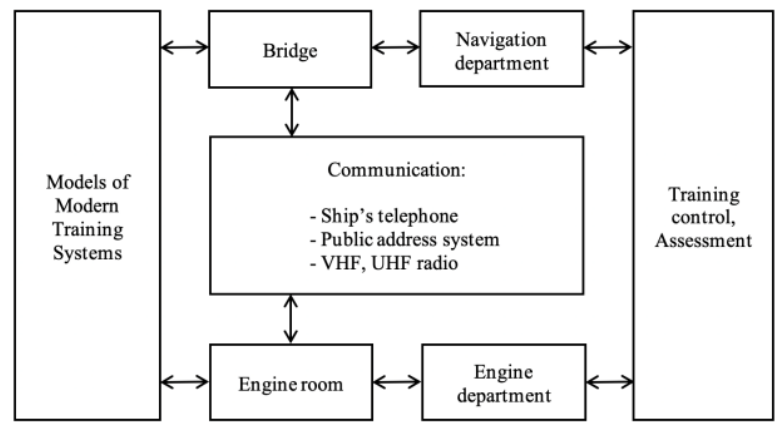

Fig. 1 The structure of training of marine specialists on simulator

Flexible training on simulators forms not only theoretical and practical skills among students, but also allows them to show personal qualities when training as part of a bridge - engine room team. For such purposes, IMO has developed a number of model courses, which are recommended to be included to the training program.

For example, model course 4.05 "Energy-Efficient Operation of Ships," 2014 edition [10], is designed to facilitate training to improve the energy efficiency of ship operation. The course contributes to achieving the IMO environmental goals set out in resolutions A.947 (23) and A.998 (25) by disseminating the "Best Practice" in the maritime industry, which reduces greenhouse gas (GHG) emissions and the negative impact of shipping on global climate change. Thus, the course content reflects the guidance for the development of the "Ship Energy Efficiency Management Plan (SEEMP)," MEPC Resolution 63.

The requirements and chapter III of International Convention on Standards of Training, Certification and Watchkeeping for Seafarers (STCW) with Manila amendments include the standards and requirements for the competence of engine room personnel at the operational and management levels [5]. In this case IMO developed a number of recommended model courses (7.02 [11], 7.04 [12], 7.08 [13], 2.07 [9]), which describe in detail the principles of training, methods of demonstration and lists of competencies that engine room personnel must be fully consistent with.

The competency tables also describe the minimum knowledge, understanding and professional skills regarding state-of-theindustry ship's systems for controlling propulsion systems, including electric propulsion.

Nowadays, there are many famous manufacturers of virtual marine simulators such as "Kongsberg" [14], "Transas (Wartsila)" [17] and others. Such simulators include a wide range of virtual simulators to provide effective training for cadets and marine crew in order to develop vital skills that promote safety, profitability and stability during work at sea.

The entire training process takes place on virtual systems of simulators and provides good theoretical knowledge. Unfortunately, during the training, there is no sense of physical realism of the real ship equipment, which cadets and crew members have to work on in the future.

Marine simulators must satisfy the international requirements and standards for conduct training and competency assessment. The world's largest international association of Classification Societies (IACS) member DNV GL, which is a leading provider of classification, certification, verification and training services, has developed a standard for marine simulations [4]. The purpose of the standard is to ensure that the simulations provided by the simulator include an appropriate level of physical and behavioral realism in accordance with the requirements for training and competency assessment. To ensure physical and behavioral realism, as indicated in [4], the simulator must be like real equipment to a certain extent to allow the delegates to demonstrate appropriate skills. Such realism should include the capabilities, limitations and possible errors of such equipment. The standard describes the classes of simulators and their application areas; a list of competencies that should be covered during training on these simulators; requirements and a list of ship systems.

The concept of conducting combined training and competency assessment simultaneously on the virtual and real simulator will allow to improve qualitatively the training process and the competence of delegates.

\section{Multifunctional simulator}

Based on the IMO model courses and recommendations for training on virtual and real simulators, the structure of a specialized multifunctional simulator (Fig. 2) and a hardwaresoftware complex for engineering modelling are given. In addition, high-quality education and training of marine specialists, as well as scientific research are proposed.

\begin{tabular}{|c|c|c|c|}
\hline Hardware & & & \\
\hline $\begin{array}{l}\text { Tasks for training } \\
\text { marine specialists }\end{array}$ & Simulators & & \\
\hline \multirow{2}{*}{$\begin{array}{l}\text { Training Task } \\
\text { Editor }\end{array}$} & \multirow{2}{*}{$\begin{array}{c}\text { Models of Modern } \\
\text { Training Systems }\end{array}$} & Software & \\
\hline & & \multirow[b]{2}{*}{$\begin{array}{l}\text { Engineering } \\
\text { Modeling } \\
\text { "ANSYS" }\end{array}$} & Competence \\
\hline $\begin{array}{l}\text { Propulsion system: } \\
\text { - Mechanical } \\
\text { - Electrical } \\
\text { - Hybrid }\end{array}$ & Training & & $\begin{array}{l}\text { Training Control, } \\
\text { Assessment }\end{array}$ \\
\hline & Hardware an & are Complex & \\
\hline
\end{tabular}

Fig. 2. The architecture of the training complex

\subsection{General overview}

A distinctive feature of the proposed simulator is an integrated approach, where the platform of the software and hardware complex makes it possible to integrate hardware, simulators, software with high output quality of competence based on a training control and assessment system.

Such multitasking implements high-quality education and training of marine specialists, as well as conducting research after 
processing of the results of engineering modeling of structural, thermal power, hydraulic, electrical, electronic, multi-physical and other solutions. The need to use the training complex allows us to form the necessary competence of the engine room personnel, develop methods and criteria for assessing competence, evaluate and demonstrate practical skills.

When decomposing the tasks that are implemented in the hardware and software of the simulator's complex, methods of system analysis were used. Each module of the multifunctional simulator implements certain tasks and goals. The training equipment includes a number of hardware simulators and makes it possible to use a database and a monitoring system for a real ship with subsequent intellectual processing of the received data and modeling of nominal and emergency situations. In fig. 3 the structure of a module of a high-voltage simulator with the electric propulsion system is shown.

Such a simulator complex reproduces most of the ship's operating conditions and allows making training with monitoring, control and management of low-voltage and high-voltage power plants and propulsion systems.

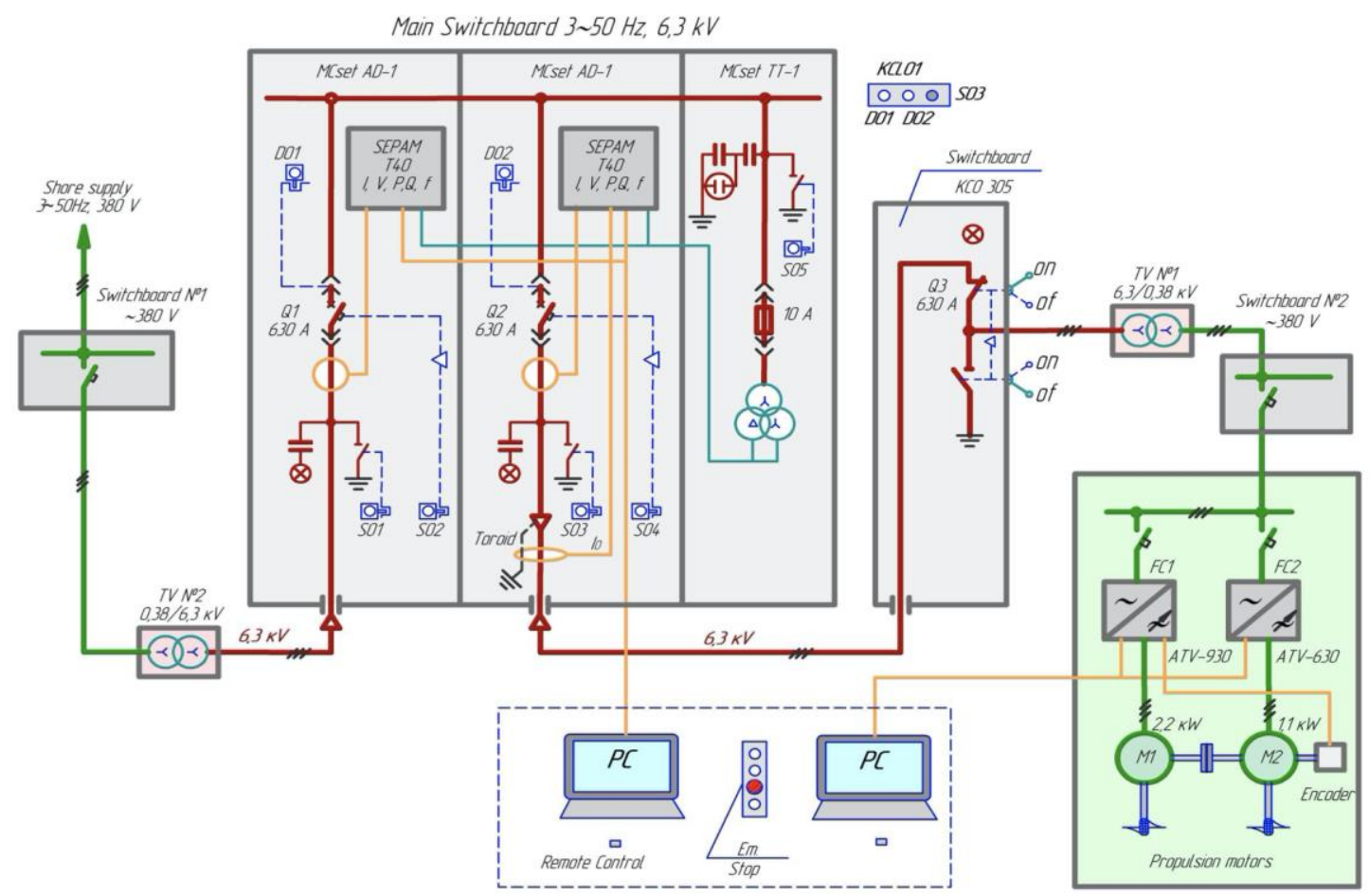

Fig. 3. Structure of electric propulsion high voltage simulator

\subsection{Hardware}

To ensure the rapid reconfiguration of the multifunctional simulator, designed to simulate the ship operating modes of various classes, it is advisable to use the modular principle in the development of hardware. This allows a simple configuration change. The layout of the hardware of the developed training complex is shown in Fig. 4.

The simulator includes the following equipment:

- two asynchronous electric motors which shafts are rigidly connected by a coupling;

- each electric motor is controlled by a frequency converter;

- software "So Move" (Schneider Electric).

Technical parts of the simulator equipment.

1. Asynchronous motor:

type: A02-22-2. $\Delta / \mathrm{Y}, 220 / 380 \mathrm{~V}, 50 \mathrm{~Hz} 7.8 / 4.5 \mathrm{~A} ; 2.2 \mathrm{~kW}$, $2860 \mathrm{rpm}, \cos \varphi=0.8$.

2. ATV630 frequency converter (Schneider Electric): $3 \mathrm{~F}, 4 \mathrm{~kW}$, $380-480 \mathrm{~V}, 50-60 \mathrm{~Hz}, 6 \mathrm{~A}$ at $380 \mathrm{~V}$; output frequency 0.1$500 \mathrm{~Hz}$.

3. Asynchronous motor (3-speed):

type: AO-6-4-2. $380 \mathrm{~V}, 50 \mathrm{~Hz}$;

$2 \mathrm{p}-6(\mathrm{Y})-960 \mathrm{rpm}, 2.5 \mathrm{~A}, 0.79 \mathrm{~kW}, \eta=69 \%, \cos \varphi=0.67$;

$2 \mathrm{p}-4(\Delta)-1460 \mathrm{rpm}, 2.6 \mathrm{~A}, 0.9 \mathrm{~kW}, \eta=71 \%, \cos \varphi=0.73$;

$2 \mathrm{p}-2(\mathrm{YY})-2880 \mathrm{rpm}, 2.9 \mathrm{~A}, 1.1 \mathrm{~kW}, \eta=70 \%, \cos \varphi=0.90$.

4. ATV930 frequency converter (Schneider Electric):

3F, $4 \mathrm{~kW}, 380-480 \mathrm{~V}, 50-60 \mathrm{~Hz}, 9.3 \mathrm{~A}-380 \mathrm{~V}$; output frequency $0.1-500 \mathrm{~Hz}$.

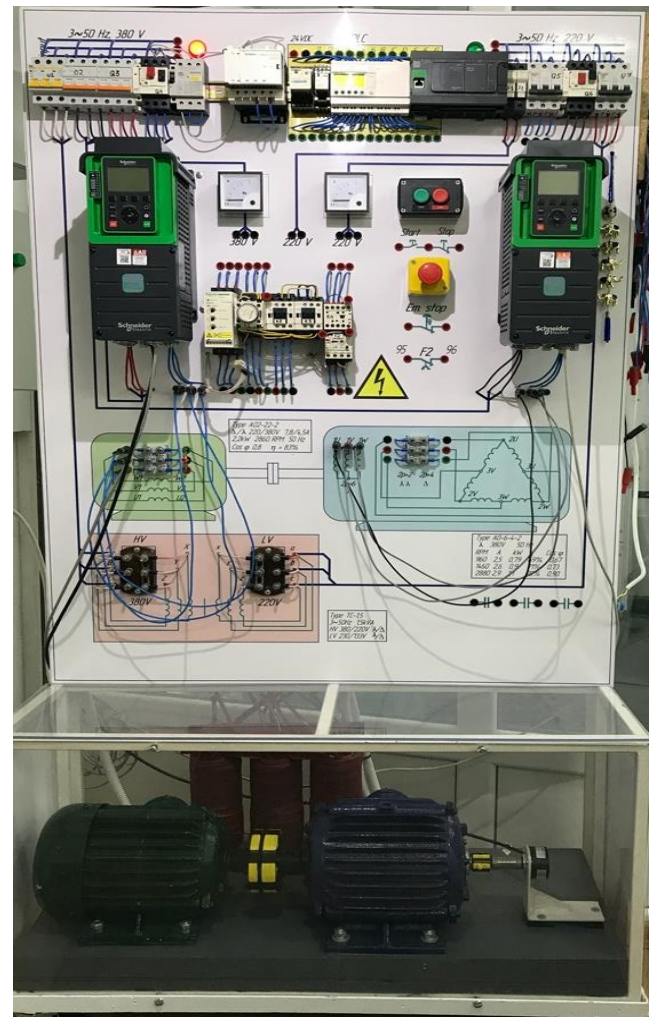

Fig. 4. Hardware of the electric propulsion simulator 
One of the motors is controlled by ATV630 like a propulsion motor and the other motor (multi-speed) is controlled by ATV930 like a load with the possibility of controlling the torque on the shaft (propeller simulator with variable pitch propeller (VPP) or fixed pitch propeller (FPP), depending on preset parameters). Thus, the simulator can be used in various modes, changing the speed of rotation of the power plant, as well as changing the load on the power plant.

On this simulator, mainly steady-state modes are analyzed: mechanical performances, curves of changes in frequency, voltage, stator current, etc. with various methods of frequency control. Dynamic modes are studied not only at idle, but also at different values or laws of load change.

The use of bi-directional frequency converters in the hardware of the training complex allows studying of ship power systems in which energy recovery modes are implemented. An example of such ship's power plants are hybrid propulsive complexes, power take-off complexes and others that can improve the energy efficiency of the marine industry through the rational use of fuel combustion energy. The implementation of such installations, on the one hand, leads to increase of technical means survivability and reduction of harmful emissions into the environment, and on the other hand, equipment control algorithms are significantly complicated. This leads to an increase in requirements for marine personnel competence.

To change the configuration of the hardware of the electric propulsion to hybrid propulsion, it is enough to integrate the module with energy storage and change the algorithms of the propulsion system at the software level.

\subsection{Software}

Various algorithms for the operation of programmable controllers, depending on the configuration of the hardware, allow flexible enough to choose the optimal operating modes of the propulsion system in accordance with the goals and objectives. Such a solution makes it possible to carry out complex modeling of various modes using databases from real ships, on which it has possibilities to record all monitoring parameter data into an integrated automation system (IAS).

On the proposed multifunctional simulator, the propulsion system using the So Move software is controlled.

Using the "So Move" software from the simulator operator panel (Fig. 5) it is possible to implement various speeds and load modes with the ability to observe and register all processes, record parameters, and form the graphical and screw characteristics of the propulsion system [2].

Using the operator panel, the following basic operations are performed:

setting and editing the parameters of the frequency of the converter;

visual display of the state of parameters and variable drives; automatization of the experimental research;

oscillography of the measured coordinates;

intellectual processing of the experimental research results and modeling of the standard and emergency situations [16].

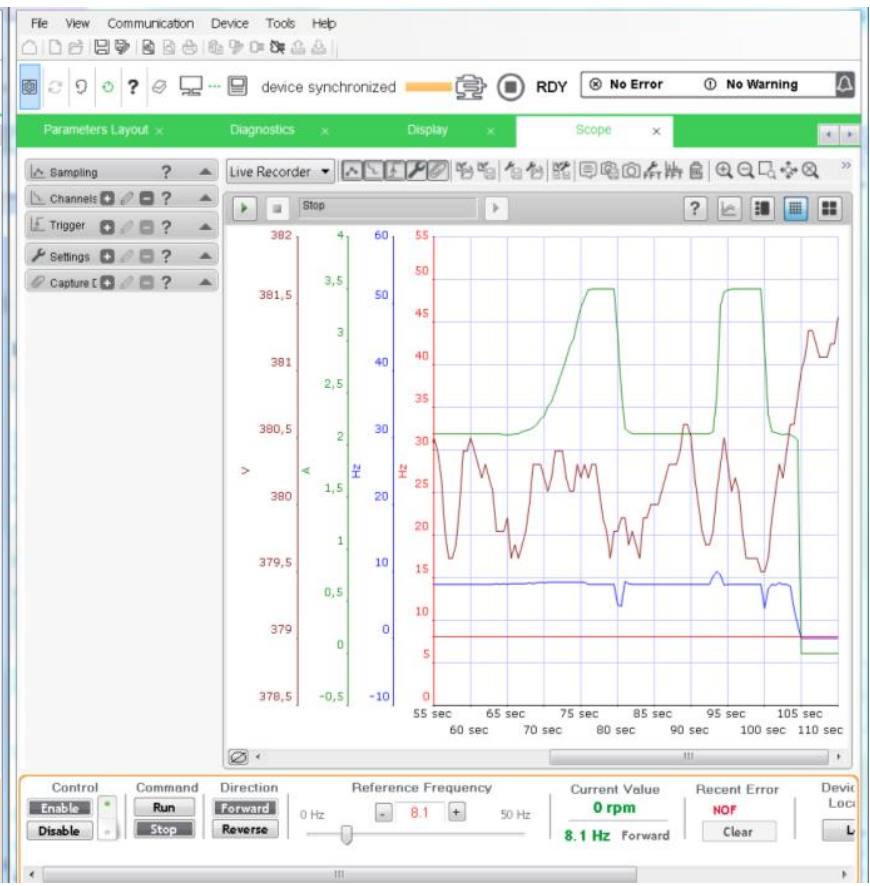

Fig. 5. Software on the operator's panel

\subsection{Results of simulations}

Modern ships use up-to-date technologies, and in particular, IAS (Integrated Automation System) implemented automated control system of ship's electric power plant gives possibilities to record the history of numerous monitoring parameters of the power management system.

In case of malfunctions or system failures, it is always possible to track which parameters of the system have gone out of operating range and analyse what happened as a result.

For example, let us consider a diesel-electric propulsion 3D class seismic vessel with wide stern for streamer towing (equipment for a seismic survey). Power of aft azimuth thrusters is $2 \times 4000 \mathrm{~kW}$, bow thruster is $1 \times 2000 \mathrm{~kW}$ and the power system of the vessel includes four main diesel generator sets of $3355 \mathrm{~kW}$ each, the main switchboard (MSB) consist starboard (STBD) and port side (Port) sections, the nominal voltage of $4160 \mathrm{~V}$ and frequency of $60 \mathrm{~Hz}$.

In this case, a module of the electric propulsion system integrates into the multifunctional simulator. The module includes a propulsion motor (PM) operated by a frequency converter and a propeller (asynchronous motor) that is a load (torque) for PM operated by another frequency converter.

Fig. 6 shows a general view of the main components of the Power Management System:

- main generators, which are located in STBD and Port engine rooms, separated by a watertight bulkhead.

- the switchboards with high and low Volt are physically segregated in port and starboard switchboard rooms and 
equipped with a segregated, PS \& SB redundant UPS system supplying all vital consumers.

- the 2 different propulsion lines powered by 3 separate electro motors with double stator windings and ABB ACS 6000 redundant drives. Electric motors and all their vital auxiliaries are located in 2 separate propulsion rooms. The 2 of individual main propulsion units use to mitigate the above situation if one propeller unit failure and in addition an independently steerable azimuth thruster in the bow.

The general structure of Integrated Automation System (IAS) are shown in Figure 7. It includes several operation stations in various ship rooms, such as the engine control room (main operation station), the bridge, the starboard and portside main switchboards, the auxiliary equipment room, the offices of the captain and chief engineer. All vital parts of the system have dual power supply from each of the two central UPS systems. If one of the redundant power supplies is lost, the system will hot-swap to live power supply without a power drop.

All vital communication in IAS system is done with dual, redundant communication bus. The system consists of several servers and computers with dual redundancy of the data received to increases reliability.

In figure 8 the separate windows with data and information on the current status of the propulsion system are displayed. It gives wide opportunities to the crew personnel to carry out the appropriate maintenance, to analyze the state of the ship propulsions, to take measures to prevent malfunctions and as well as to display the playback history of parameter changes when various malfunctions and emergencies occur.

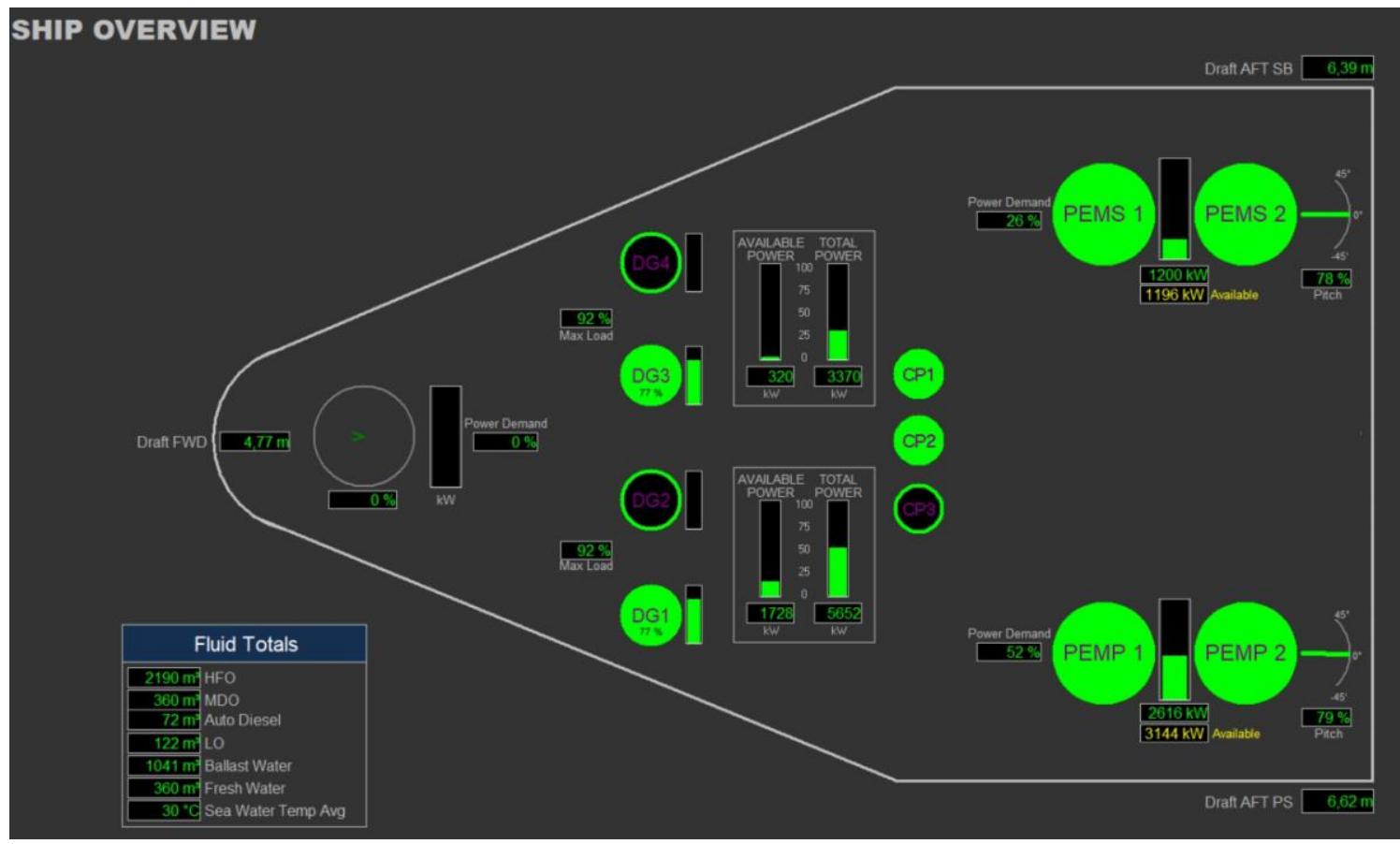

Fig. 6. Power Management system overview

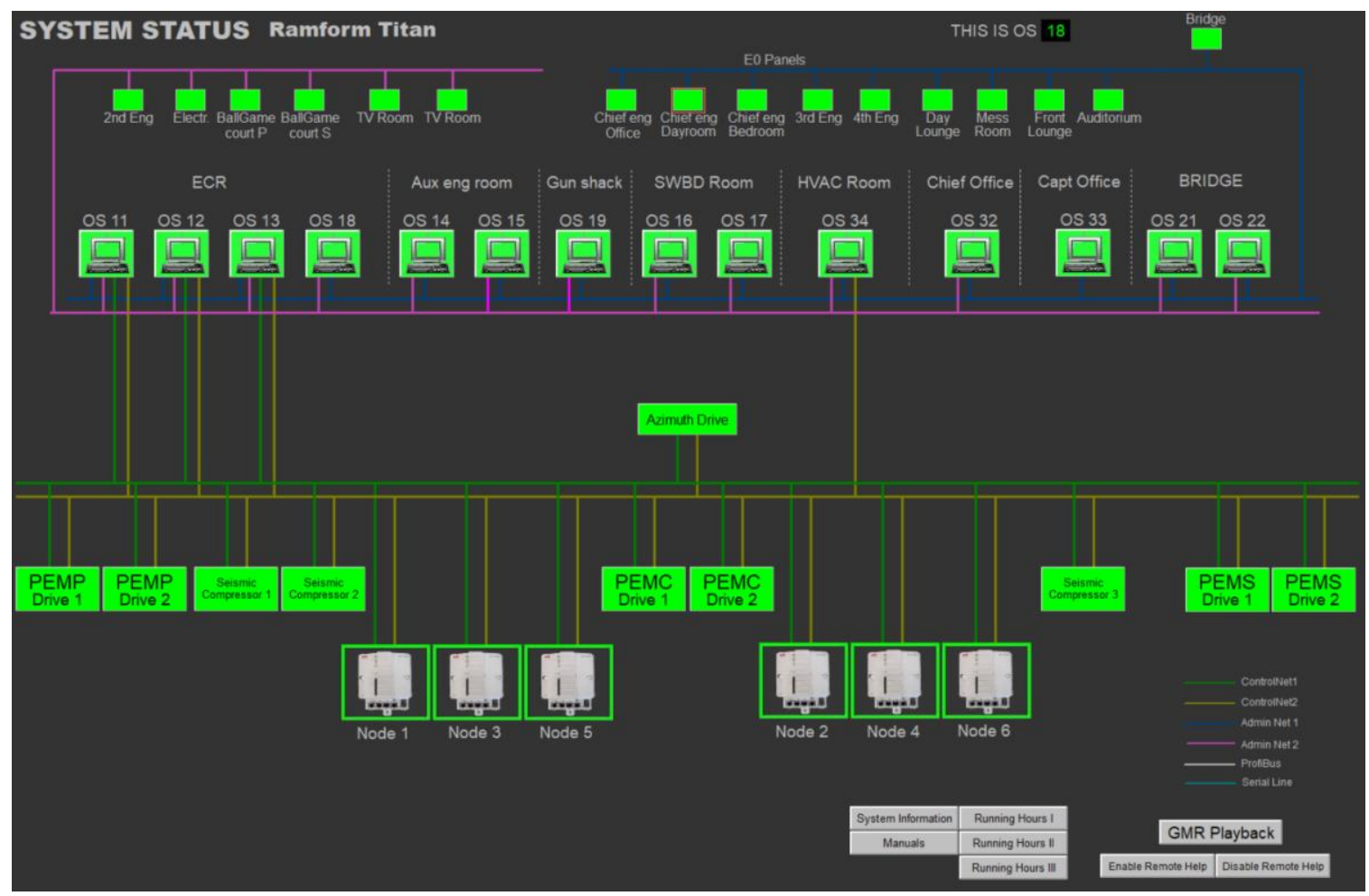




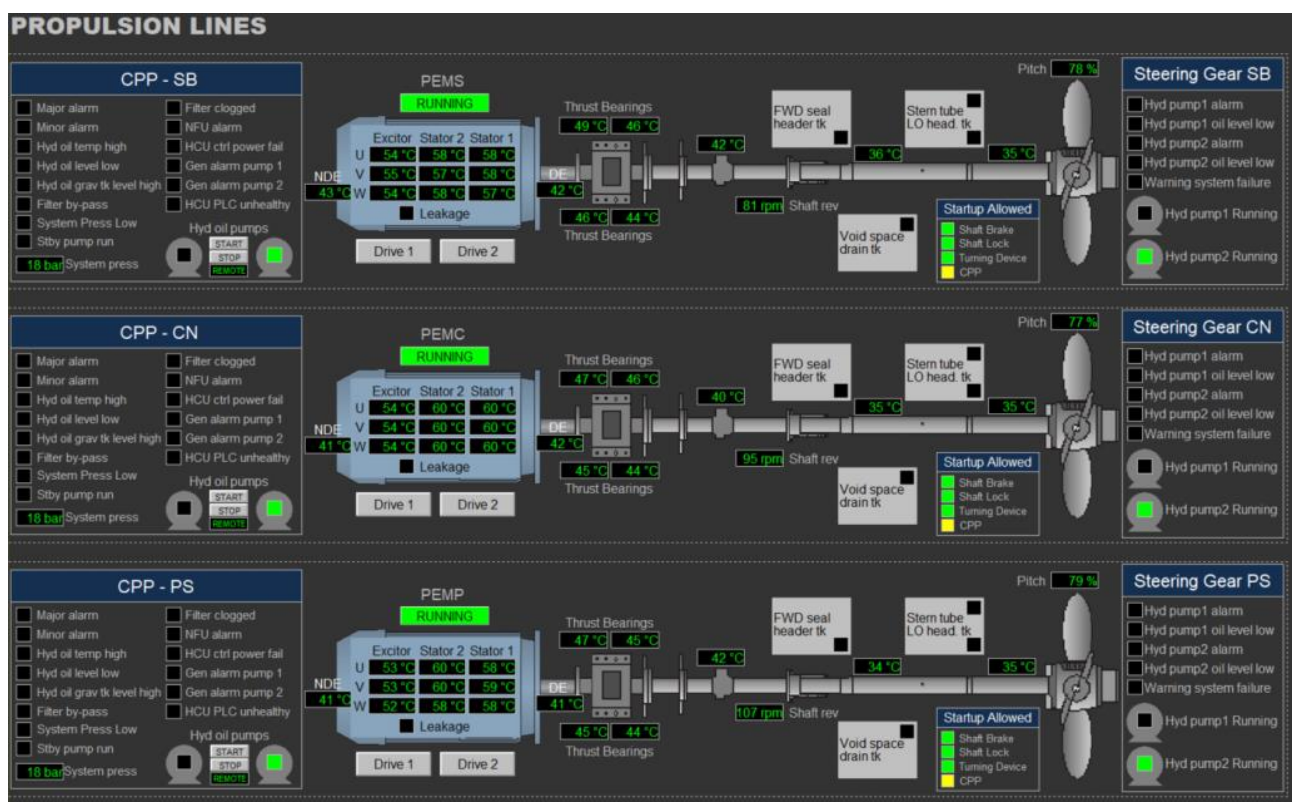

a) propulsion mnemonic

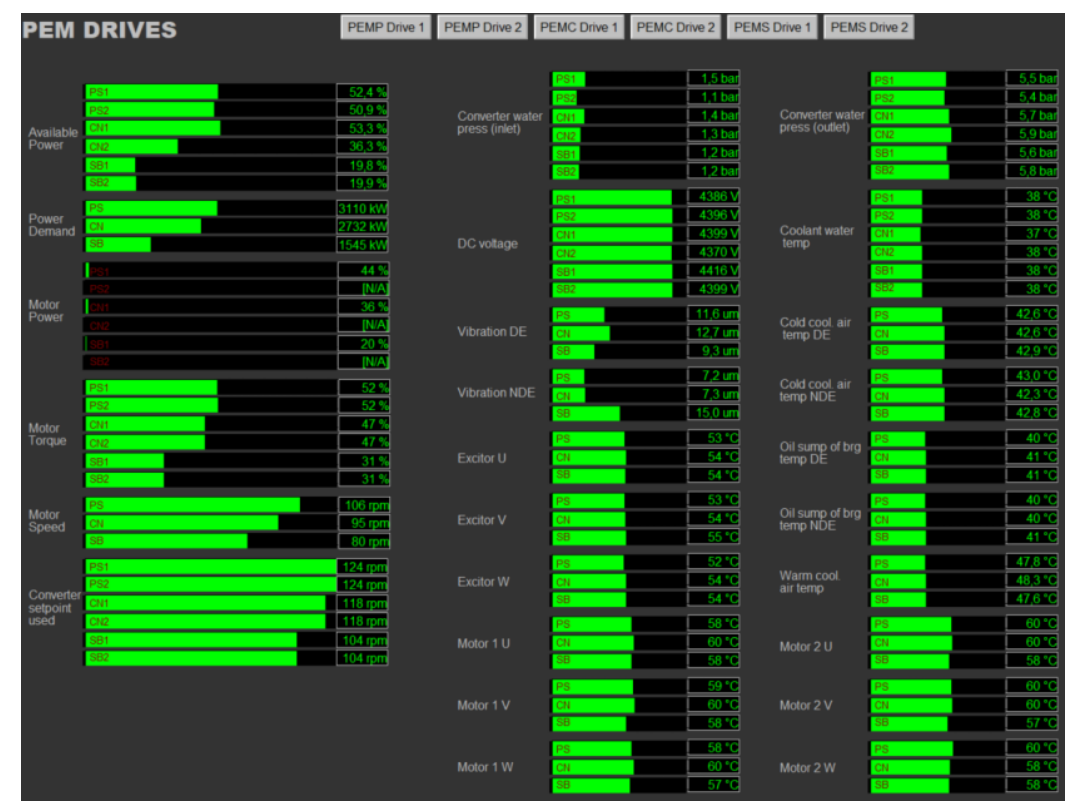

b) parameters propulsion drive system

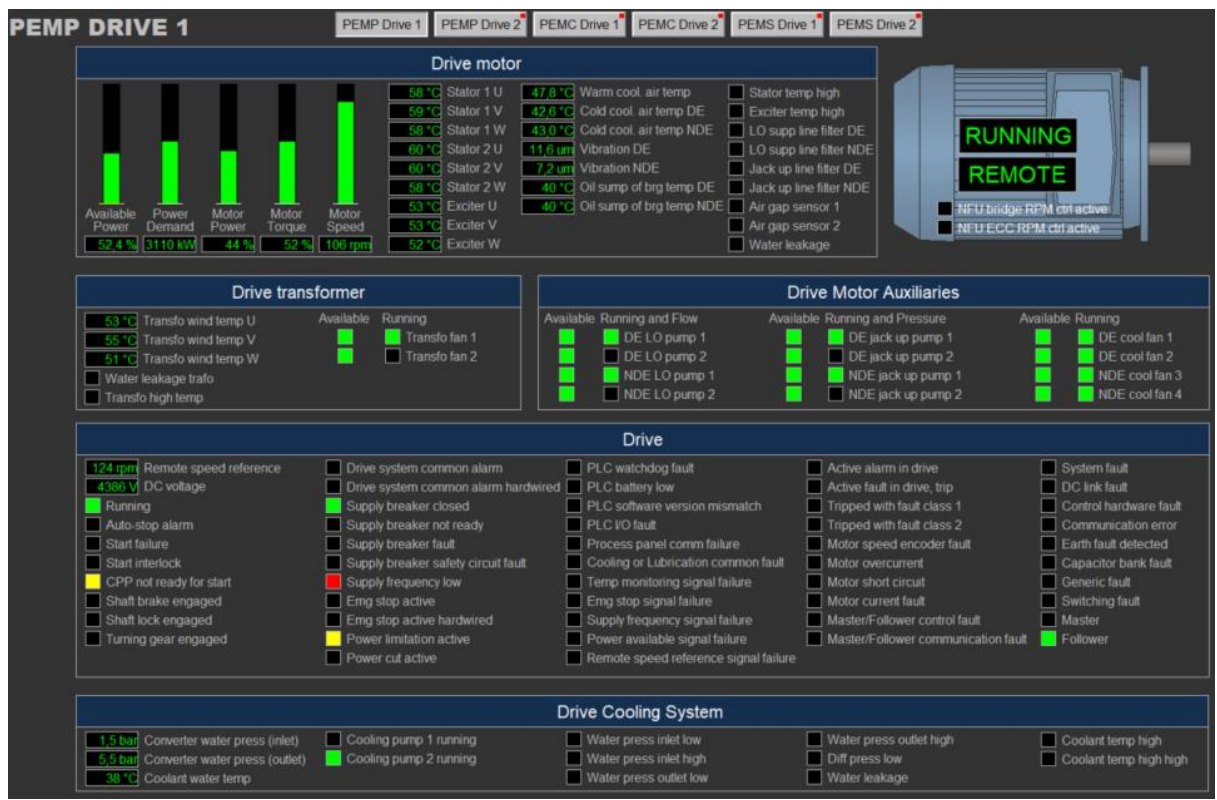




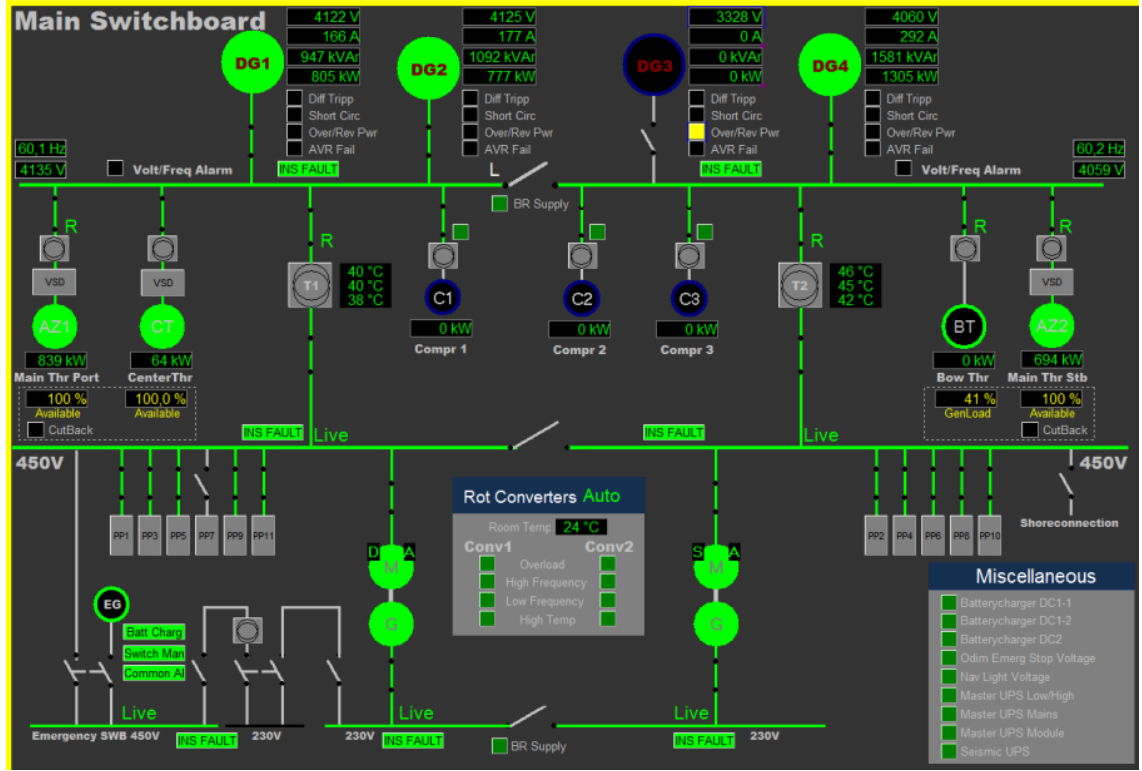

Fig. 9. Mnemonic of High Voltage Main Switchboard

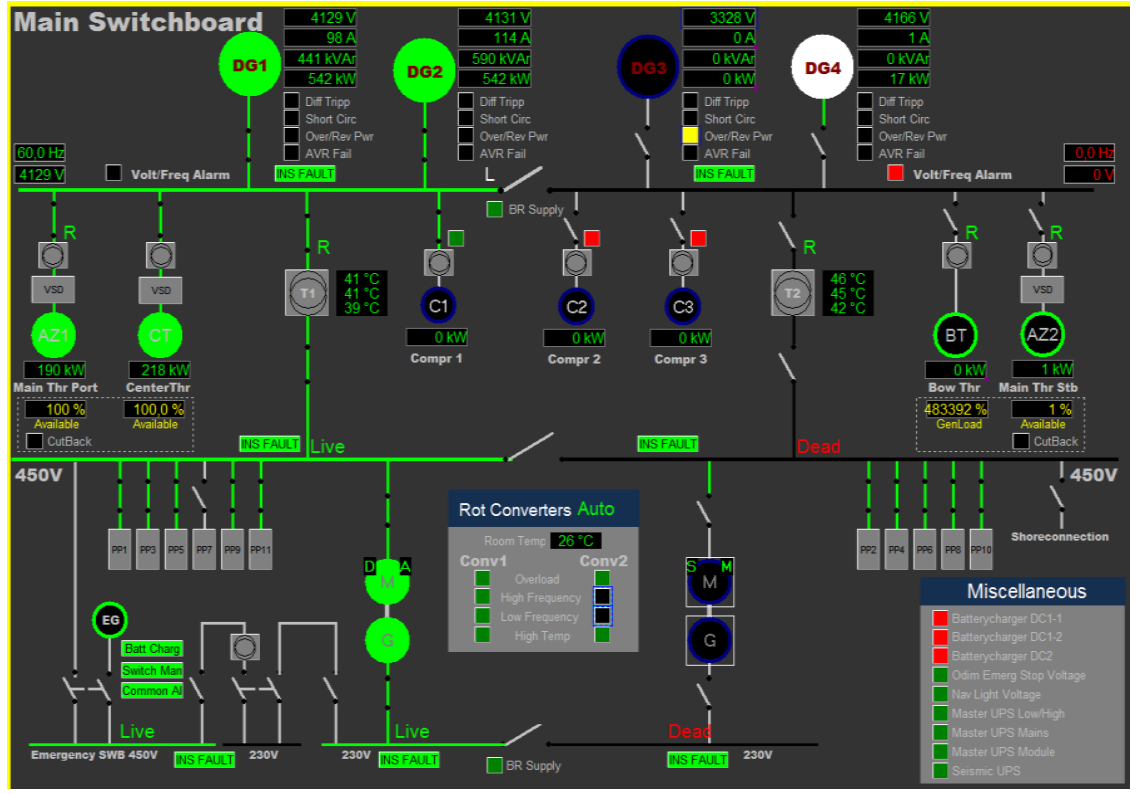

Fig. 10. Emergency situation and partial blackout

Each parameter displayed on the screen is recorded in a database, which stored on servers for an average of 3 to 6 months. Where applicable, the recording history can be retrieved to playback, save or analyze the system status.

By means of control algorithms on the multifunctional simulator, different modes of operation (nominal and emergency) are implemented. The simulator gives various loading ranges, which reproduce general operation of the propulsion system, simulation of overloads, suddenly increase and decrease loads and emergencies that occurred or would occur on the diesel-electric propulsion vessels.

Simulation of high voltage PMS of dynamic positioning (DP) diesel-electric propulsion of seismic vessel in the operating mode under the rough state of the sea with wave height up to 8 meters was performed.

A particular feature of this operation mode is that during the seaway of a vessel, propellers are exposed which cause the sudden changes of load for propulsions. Monitoring system window in this situation is shown in figure 9. It can be seen that the loads on the generator sets and thrusters are distributed extremely unevenly.
In this case, trainees should pay attention to the understanding of processes in operating the propulsion system, such as static, dynamic characteristics of power units, parameters of operation modes and character of transient processes.

Based on the analysis of the current load and the dynamics of its change, the operator must make a decision to reconfigure the power system in order to avoid overloading or an emergency situation in the future.

Any loss of electrical power, propulsion or steering functions must immediately be brought to the attention of the Chief Engineer and Master.

The vessels are equipped with back-up systems for all safetycritical equipment including electrical power, propulsion and steering. Vessel specific checklists for the operation of these systems must be followed to restore the lost functions as quickly as possible. Blackout recovery procedure is described in [15].

The result of simulation of such an emergency when the operator took the wrong decision is shown in Fig. 10.

Untimely or wrong actions of the operator resulted partial blackout of STBD HV switchboard and all power consumers are supplied from this side and emergency shutdown of the propulsion motors. The training complex also allows simulating elimination of emergency. 


\section{Control of the training process}

Monitoring of training process is necessary to implement rational management of the process and form an individual trajectory to increase the effectiveness of training.

The management system of training quality, which is based on the competency-based approach, should consist of three interconnected modules: a subsystem for assessing the results of a delegate's activity, a subsystem for identifying his psychophysiological state, and a subsystem for forming a simulator's intellectual information environment.

To determine the level of professional competence, the quality and proficiency of knowledge, skills and abilities assimilation, motivation, activity and successfully completed tasks in solving practical training are evaluated. Training control is traditionally carried out in the form of testing in the practical exercises.

Identification of a person state can be carried out on the basis of determining biological parameters during the execution of different nature operations. To process the measurement results, it is advisable to use the methods of fuzzy logic. That allows us to timely identify critical deviations of the psychophysiological parameters of the delegate and adaptively configure the training process [3].

Individual correction of specialist training contributes to the elimination of erroneous actions, development of positive abilities by adjusting the complexity of tasks, selecting tasks corresponding to the specialization of training, and redistributing the time for their implementation.

\section{Conclusions}

The uniqueness of the simulator complex is that in addition to real simulators, virtual simulators with various modern models, systems of marine vessels are integrated into the software, and hardware complex, which makes this simulator complex multitask, universal and flexible in achieving a variety of tasks and goals.

\begin{abstract}
M.Sc. Artem Ivanov
e-mail: artiva1978@gmail.com

Ph.D. student of Kherson State Maritime Academy, Department of Ship Electrical Equipment and Automatic Devices Operation. Head of department of courses in ship's marine engineering Kherson Maritime Specialized Training Centre. Research Interests: marine engineering, software engineering, energy systems.
\end{abstract}

http://orcid.org/0000-0002-1919-2570

\section{M.Sc. Igor Kolosov
e-mail: ikolosov@ marlow.od.ua}

Graduated in 1998 from Odessa Maritime Academy as a maritime navigator. While studying at the Academy, he began his career at sea and got position Chie officer. Since 2003 works at Marlow Navigation Ukraine and holds the position Director of Crewing Department.

Research interest: optimization of training process management of marine personnel.

http://orcid.org/0000-0001-9572-587X
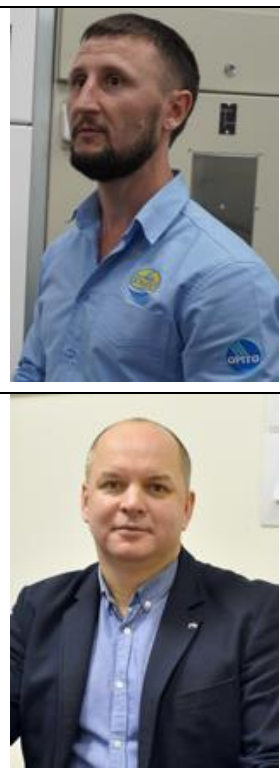

M.Sc. Vadim Danyk

e-mail: vadymdanyk@gmail.com

Assistant of Department of Ship Electrical Equipment and Automatic Devices Operation, Kherson State Maritime Academy.

The field of scientific interest is hybrid marine propulsion systems, marine power systems.

Based on "ANSYS" software and engineering modelling, the data and results, obtained during the work and training with hardware simulators, are processed and simulated by heat-power, hydraulic, electrical, electronic or multi-task solutions both for improving the functionality and for research activities.

Training of marine specialists on simulators provides many opportunities for the implementation of various scenarios, as well as training of a whole team of navigational and engine room officers.

\section{References}

[1] Geertsma R., Negenborn R., Hopman J.: Design and control of hybrid power and propulsion systems for smart ships: A review of developments. Elsevier 2017.

[2] Ivanov A.A., Lebedenko Yu.A., Rozhkov S.A., Kolosov I.V.: Electric Propulsion Ship's Training Simulator Based on Intelligent system. International scientific journal Electronics and Control Systems 2(60), 2019, 53-60.

[3] Kuznetsov M., Rudakova H., Kolosov I.: The application of fuzzy logic to identify the personal state of the human operator. Computer-integrated technologies in the present: a collection of scientific works of young scientists, Kherson 2016, 15-19.

[4] DNV GL Standard. DNVGL-ST-0033. Maritime simulator systems. Edition: March 2017.

[5] IMO: International Convention on Standards of Training, Certification and Watchkeeping for Seafarers, (STCW Code). London 2017.

[6] IMO: Marpol, AnnexVI and NTC 2008. London 2017.

[7] IMO: Marpol. London, 2017.

[8] IMO: MEPC 63/23 Annex9. London 2012

[9] IMO: Model Course 2.07 Engine-Room Simulator. London 2017.

[10] IMO: Model Course 4.05 Energy Efficiency Operation of ship. London 2014

[11] IMO: Model Course 7.02 Chief Engineer Officer and Second Engineer Officer London 2014

[12] IMO: Model Course 7.04 Officer in Charge of an Engineering Watch. London 2014.

[13] IMO: Model Course 7.08 Electro-Technical Officer. London 2014

[14] https://www.kongsberg.com/digital/products/maritime-simulation/k-sim-engine/ (available 26.01.2020)

[15] https://www.pgs.com/marine-acquisition/tools-and-techniques/the-fleet/ (available 26.01.2020).

[16] https://www.se.com/ww/en/product-range-presentation/2714-somove/\#tabs-top (available 26.01.2020).

[17] https://www.wartsila.com/marine/optimise/simulation-and-training (available 26.01.2020)

\begin{abstract}
M.Sc. Sergey Voronenko
e-mail: vr.sergey@ukr.net

Assistant of the Department Operation of Marine Electric Equipment and Means of Automation of Kherson State Maritime Academy.

Research interest: optimization of control of ship complex electric power turbo compressor units.
\end{abstract}

http://orcid.org/0000-0002-3880-9556

\section{e-mail: lebedenko@kntu.net.ua \\ Assistant professor of Department of Automation, Robotics and Mechatronics, Kherson National Technical University. \\ The fields of scientific interest are adaptive and optimal control systems, marine power systems. The author of more than 80 scientific papers.}

http://orcid.org/0000-0002-1352-9240

\section{Prof. D.Sc. Hanna Rudakova}

e-mail: rudakova.ganna@ kntu.net.ua

Professor of Department of Automation, Robotics and Mechatronics, Kherson National Technical University. The fields of scientific interest are modeling of complex systems, automation of control processes, identification of critical operating modes of equipment.
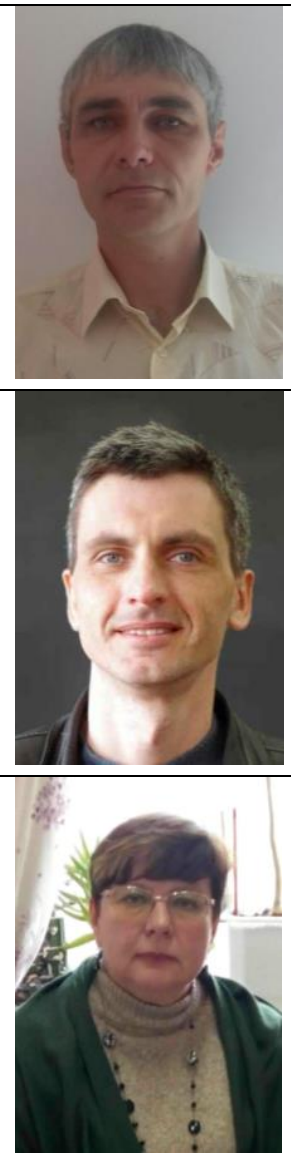